\title{
ERROR ANALYSIS OF ELEVENTH GRADE ODD MIDTERM EVALUATION IN VOCATIONAL SCHOOL MUHAMMADIYAH 2, TANGERANG
}

\author{
Woro Endah Sitoresmi ${ }^{1}$ \\ Institut Teknologi \& Bisnis Ahmad Dahlan, Jakarta \\ woroendah62@gmail.com \\ Velma Alicia ${ }^{2}$ \\ Institut Teknologi \& Bisnis Ahmad Dahlan, Jakarta \\ velma.alicia@gmail.com
}

\begin{abstract}
The objective of this study is to know the grammatical errors and to elaborate the sources of errors in odd midterm evaluation of eleventh grade for the academic year 2018/2019 in Vocational School, Muhammadiyah 2, Parung Serab, Kota Tangerang, Banten. It belongs to descriptive qualitative study which used document analysis to proceed the data. The findings showed that there are five error grammatical items which include tenses (present tense \& past continuous tense), preposition, object pronoun, article and quantifier. In addition, there are three sources of errors in the study; error related to context of learning, intralingual error and interlingual error.
\end{abstract}

Keywords: error analysis, intralingual, interlingual

\section{INTRODUCTION}

As one of the international languages, all sectors use English language terminology to give ease description for certain thing including educational terminology such as material, pronunciation, synonym, antonym, etc. However, it is not an easy way to master English language which the people don't belong that language as the first language or their mother tongue like Bahasa Indonesia because the people will find some different pronunciation, diction or even grammar when they to put these certain words into some meaningful sentences. The people can't avoid some errors including syntax, phoneme or morpheme when they use English language in their practice (Suseno: 2014). It means that they will pass the dynamic process through their errors between the two languages, Bahasa Indonesia and English Language.

Kiser (2009) claimed that errors in learning foreign language are the process which reflects the interlanguage competence. Furthermore, it becomes the evidences for every learner to catch the new words in the process of second language acquisition. To argue that the error analysis is a crucial part in the process of teaching and learning English language because it provides the linguistic parts which represent the core of language system. In line with this agreement, Erdogan (2005) stated that making errors in English language shows the cognitive process for recognizing and coding the target language.

Although, English language in Indonesia becomes English Foreign Language (EFL), in a non-government school such as vocational school Muhammadiyah 2 Tangerang, to master English language is a point plus for both of teachers and students to master an international language such as English language in order to compete the students themselves in globalization era. It might be said that the use of English language is really appropriate for the students in line with the book as the 
reference for both teachers and students. Other reason why non-government school such as vocational school Muhammadiyah 2 Tangerang puts this way because the school itself wants to improve students' ability in English language whether in reading skill, listening skill, speaking skill, writing skill and cultural skill separated from the language lesson itself.

In mastering these four English skills, the teachers are required to have outstanding ability to deliver the materials for the students which include pedagogical ability, linguistic ability, method of teaching, the textbook or course book so that the students can catch the materials well. Furthermore, students' understanding can be seen how they do daily evaluation (worksheet, homework, project), midterm evaluation and finalterm evaluation given from the teachers. These evaluations become measurement tool to see the depth materials that have been achieved by the students. From these evaluation also, the teachers can evaluate their performance particularly in the method of teaching. It might be concluded that every evaluation can give big impact for both teachers and students particularly to see their progress on each other.

To achieve the goal in mastering English language, the analysis of grammatical errors is hardly important to do because it becomes the negative transfer for the second language material particularly in the process of teaching and learning in the school. Within the grammatical errors also can lead the students into better progress so that they have good evaluation for both teachers in delivering the materials and the students in receiving the material from the process of teaching and learning in the classroom. Therefore, the writers formulate two research questions. Firstly, it related to kinds of grammatical errors in the odd midterm evaluation of vocational and finding out the sources of errors in this sheet.

\section{LITERATURE REVIEW}

2.1. The Nature of Error

Brown (2007) highlights the definition of error from the point of view extern point; the lack competence of the learners. Ellis (2008) stated that error can be global errors and local errors. However, it is clear that errors can affect the sentence meaningfully and grammatically. It is important to have study of error then which is called ad error analysis (EA). Krashen (2006) claimed that EA is a new method to increase students' understanding in learning langauge. In line with this, Brown (2000) elaborates EA as the process to observe, analyze and categorize the errors such in detail. James (2008) also formulated EA as a new way of learning to identify which materials have been mastered by the students. To say that EA is very useful in the process of teaching and learning and also helps to reveal the types and sources of errors whether they belong interlanguage or intralanguage which can lead to an accurate way and to reduce errors or grammar overgeneralization made by learners in the concept of second language acquisition.

\subsection{The Classification of Error}

Suseno (2014) claimed eight elements that become the most important parts to understand grammatical English particularly for writing class. They are consistency of subject and verb tenses, consistency of plural and singular forms, consistency of parallel construction, tautologies and redundancies, misplaced modifiers, misplaced pronouns or faulty 
references, passive construction and choice of verb forms. According to Krashen (2006), error has four categories; omission (the absence of the item that must become the part of the structure), addition (the existence of certain that mustn't be part in the structure), misformation (the use the incorrect of the morpheme of structure) and misordering (wrong position of certain morpheme in the structure. It usually happens because of literal translation). However, James (2008) proposes errors based on part of speech (adjectives, adverbs, articles, nouns, possession, pronouns, prepositions and verbs), substance errors (capitalization, punctuation and spelling), lexical errors (word formation and word selection), syntactic errors (coordination/ subordination, sentence structure and ordering), and semantic errors (ambiguous communication and miscommunication).

\subsection{Source of Error}

According to Selinker on Nzama (2010) proposed five sources of errors; language transfer, transfer of training, strategies of second language learning, strategies of second language communication and overgeneralization. Furthermore, Richards (2004) classified errors in practicing English language into interlanguage error (the interaction between the students' mother tongue and the language that the students learn), intralanguage error (errors that usually occur within the language that is being learned) and developmental error (error occurred from faulty comprehension of distinction in the target language).

In contrast with Richard, Brown (2000) stated that there are four sources of errors; intralingual transfer (false analogy, misanalysis, incomplete rule application, exploiting redundancy, hypercorrection, overgeneralization), interlingual transfer (mother tongue influence), context of learning (setting or situation where langauge is learnt), various communication strategies the learners use (avoidance arises, prefabricated patterns, cognitive and personality style, language switch).

\section{RESEARCH METHOD}

This research belongs to descriptive research by using qualitative design. It is because the objective of the research is to unpack the grammatical errors are found in odd midterm evaluation sheet for academic year 2018/2019. It belongs to descriptive research because it is one line with Shohamy (2001) who stated that a descriptive research is a study which investigates utilize existing data or a non-experimental research with a preconceived hypothesis. Furthermore, the purpose of the study is to analyze grammatical errors and the source of errors in midterm evaluation in academic year 2018/2019 in vocational school Muhammadiyah 2, Parung Serab, Kota Tangerang, Banten.

The data in this study is mostly in the forms of words not in the numbers. They are words, phrase and sentence. It is one line with Miles \& Huberman (2003) who claimed that qualitative data is usually proceed in the form of words and their description. The data for this research is the odd midterm evaluation sheet which becomes the main data in this study. which involved all the competencies in odd midterm of the process of teaching and learning from July- October 2018. It means that the data from the odd midterm evaluation has been studied in the classroom.

The writers proceed data collection until data analysis and interpreted by themselves actively and accurately using document analysis. The procedures in this research are (1) 
collecting the data related to grammatical errors, (2) identification of grammatical errors, (3) analyzing the items of the grammatical errors and the sources of the errors, (4) explanation of grammatical errors and the source of errors.

\section{RESULT AND FINDING}

4.1. Grammatical Error

Table 4.1 Data of Grammatical Errors

\begin{tabular}{|c|c|c|}
\hline $\begin{array}{l}\text { Grammar } \\
\text { items }\end{array}$ & $\begin{array}{c}\text { Number \& } \\
\text { Form }\end{array}$ & $\begin{array}{l}\text { Types of } \\
\text { Error }\end{array}$ \\
\hline \multicolumn{3}{|l|}{ Tenses } \\
\hline $\begin{array}{l}\text { 1.1. Present } \\
\text { Tense }\end{array}$ & $\begin{array}{c}12,13,24 \\
\text { (Multiple } \\
\text { choice) }\end{array}$ & $\begin{array}{c}\text { Misformation } \\
\text { (Alternating- } \\
\text { forms) } \\
\text { Omission } \\
\end{array}$ \\
\hline $\begin{array}{l}\text { 1.2. Past } \\
\text { Contin } \\
\text { uous } \\
\text { Tense }\end{array}$ & $\begin{array}{c}39 \\
\text { (Multiple } \\
\text { choice) }\end{array}$ & Misordering \\
\hline Preposition & $\begin{array}{c}1 \\
\text { (Multiple } \\
\text { choice) }\end{array}$ & $\begin{array}{c}\text { Misformation } \\
\text { (archi-forms) }\end{array}$ \\
\hline $\begin{array}{l}\text { Object } \\
\text { Pronoun }\end{array}$ & $\begin{array}{c}8 \\
\text { (Multiple } \\
\text { choice) }\end{array}$ & $\begin{array}{c}\text { Misformation } \\
\text { (archi-forms) }\end{array}$ \\
\hline Article & $\begin{array}{c}4 \\
\text { (Short } \\
\text { answer) } \\
\end{array}$ & $\begin{array}{l}\text { Addition } \\
\text { (simple } \\
\text { addition) }\end{array}$ \\
\hline Quantifier & $\begin{array}{c}8 \\
\text { (Short } \\
\text { answer) }\end{array}$ & $\begin{array}{l}\text { Misformation } \\
\text { (archi-forms) }\end{array}$ \\
\hline
\end{tabular}

From this data which involves multiple choice (50), short answer (20) and essay (5), it is found at least five grammar areas to be analyzed which are spread into eight numbers in two forms of question form; multiple choice and short answer. However, in the form of essay, it is not found grammar error in this odd midterm evaluation. The data in this table also become the main or resource data which the writer breaks down into grammar analysis in this following section.

\subsubsection{Present Tense}

From the resource data, there are three numbers in multiple choice form which have incorrect structure in present tense. These numbers are the highest number from all incorrect grammar structure.

In number 12 of multiple choice, the dialogue sounds "I fell comfortable here". The question has incorrect grammar structure in using verb 1 (fell). Verb "fell" doesn't belong to verb1, it is verb 2 for past tense. It means that the use of verb isn't suitable for present tense form which always uses verb 1 to express certain sentences whether it is in affirmative (+), negative (-) or interrogative (?). However, this sentence should use verb 1 "feel" to state present tense form, "I feel comfortable here". It might be said that the point of this grammar structure is located in inappropriate verb for Present tense which leads into misformation that causes wrong form or morpheme and totally changes the meaning itself.

In telling Present tense, both teacher and students are required to have excellent knowledge about its formula particularly the additional of "s/es" for the verb itself. For instance the verb "have or" has, is categorized into irregular verb as conjugation which refers to possessing, but the use of verb "have or has" is based on subject.

In the other words, it is impossible to say "our nation haves the competence" in this structure which is located in number thirteen. The question is actually uses the subject "nation" which can be pronoun as "it". The question still uses the wrong verb in the structure. It uses ".....our nation have the competence ....." to tell statement. It is totally wrong; it should be "........ our nation has the competence .......". It means that the sentence doesn't use the 
appropriate formula in putting verb 1 in this sentence. The subject "nation" always uses "verb 1 - has" not have, since it belongs to pronoun "it". Verb 1 for "have" is for the subject $I$, you, we, they while "has" is for the subject he, she, it. If the sentence still uses the structure ".....our nation have the competence .....", it will be classified into omission which refers to certain element should be put in the structure but has been omitted. It means that the verb "has" is omitted and replaced by the verb "have".

Next number which still involves incorrect use of Present tense is number twenty four. The question is about tag question which uses indefinite pronoun "nobody" in the sentence; "nobody's come to pick up the car, .......?.". It is known that every indefinite pronoun refers to singular subject that could be "she or he" although the word "nobody" can be interpreted as double meaning which the form is positive but the meaning is negative. However, the question looks so ambiguous within the answer provided in the options such as A (do they), B (don't they), C (they have), D (haven't they), E (have they). From these answers, the teacher as the creator of this question doesn't provide singular subject at all and it is written with the short (nobody's) that can be understood as "nobody has" but the teacher puts plural subject that written "they" in the given answers. It means that it is actually not found the correct answer for the question number 24. To reveal the error grammatical in this sentence comes with two options; a) nobody comes to pick up the car, ........? or b) nobody has come to pick up the car, .......?. In the option (a), it should be present tense and add "s" after verb 1 (come) to avoid omission. In the option (b), it belongs to present perfect tense and the verb still "come" because it is irregular verb without "s" in the end of the verb to avoid misformation. It means that the optional answer will follow one of two structures in this sentence.

\subsubsection{Past Continuous tense}

Past continuous related to certain action in the past time and still continued for short period in the past time. Past continuous usually is longer than past tense although both of them in the past time. In this evaluation sheet, it is still found that the question which has grammatical error related to past continuous tense. The incorrect question is in number thirty nine in the form of multiple choice.

The question in number thirty nine is asking about the subject of certain action "who picked up the phone when it rang?". The question consists of two actions in one structure. First clause is who picked up the phone and the second is when it rang. From this structure, it can be understood that the first action must be "when it (the telephone) rang" which has longer duration and the second action is "who picked up the phone?" which has shorter duration. However, this sentence has incorrect structure because the sentence has misordering structure to state it. The first action which has longer duration should belong to past continuous tense but the second action which has shorter duration should be past tense although the position does not determine it. Since the structure involves misordering, it can be seen no difference at all. The sentence should be "who picked up the phone while it was ringing?". With this correction, it is clearly seen that there are two different actions which come earlier than other action. Also, it is important to use "when or while" that "when" associates to past tense and "while" 
associates to past continuous tense although they do not have different meaning.

\subsubsection{Preposition}

The question number 1 involves incorrect preposition to indicate the place with preposition "at". The sentence sounds "...... I'll try to put you through to Mr. Agus at his office". The use of preposition "at" here is incorrect because it is not appropriate to tell general place although it does not change the meaning of the sentence itself. It means that the students still understand the point of the sentence in this number. Preposition "at" is kind of preposition to tell something at a specific point. It is clearly seen that the sentence does not involve specific point but it is referring to something inside the place (his office) so that the sentence should use preposition "in", and the sentence should be "...... I'll try to put you through to Mr. Agus in his office".

This grammatical error is considered into misformation. It is caused because the error belongs to an intralingual error which the teacher has knowledge of vocabularies and apparently free alternation of various members of class with each other without considering the use and the function.

\subsection{Object Pronoun}

Based on the question sheet of mid oddterm evaluation, it is found that there is one grammatical error which is related to word order. It is located in number eight in the form of multiple choice. The question is about the dialogue between Paul and Putri who discuss their opinion about illness. In the dialogue, Paul said to Putri "you should go to the doctor. Let I'll accompany you". It is obviously seen that the sentence has grammatical error on the use of "I'll" in the structure. Since the verb "let" needs object, it is impossible to use "I'll" in the structure because it belongs to subject. It means that the verb "let" is always followed by an object not a subject after it, so that the right structure should be "Let me accompany you". The word "me" is the object pronoun for the subject "I", so it is correct structure after using "let".

Using the structure "Let I'll accompany you", the sentence contains grammatical error in misplaced pronoun "me" from the subject "I". This grammatical error is classified into misformation because the teacher doesn't put object after the verb "let" which becomes wrong structure on it.

\subsection{Article}

It is still found a sentence which contains grammatical error in using incorrect article use in this evaluation sheet in number four in short asnwer. The question discusses about the health; "Yes, I get a headache and a stomachache". From this sentence, it can be understood that the speaker has one of headache and one of stomachache whereas headache and stomachache are classified into common disease which belong to countable noun that everybody may have one of their symptoms.

The reason why this sentence is classified into incorrect structure is the use of article in that structure. Since this sentence contains disease (such as headache and stomachache), it is unnecessary to put article " $a$ " before the disease (headache and stomachache) because disease become zero article which becomes one of common countable nouns. The appearance of article " $a$ " in front of the disease (headache and stomach) is categorized into simple addition error. It means that 
to have correct structure for this sentence, it should sound "Yes, I get headache and stomachache" by eliminating article "a" before disease.

\subsection{Quantifier}

When a structure consists of quantifier, it is related to quantity which describes certain nouns. According to the item related to quantifier in this question sheet, there is one question found that still involves the incorrect structure for indicating quantifier. It is located in short answer for number eight. Actually, the question is about yes/no question which sounds "...........(have, you) some money? I need it". It can be seen clearly that the sentence uses quantifier "some" in asking quantity of money.

However, this question could be wrong because the structure in this question belongs to interrogative pattern. Here quantifier "some" is used for affirmative sentence while "any" is used for negative and interrogative sentence. It is the reason why the writer classified the sentence into incorrect grammar. It means that the sentence could be changed into " (have, you) any money? I need it" to have correctness. This error is classified into misformation (archi-forms).

\subsection{The Sources of Errors}

In this part, the writers elaborate the sources of these grammatical errors by using Brown's theory about the source and cause of grammatical errors for English language which listed into interlanguage errors, intralanguage errors, context of learning and communication strategies the learners use.

\subsubsection{The Errors Related to Context of Learning}

Since the study is about the analysis of grammatical errors in odd midterm evaluation for vocational school of Muhammadiyah 2, Parung Serab, Kota Tangerang, Banten which the evaluation is made by the teacher, it might be said that the grammatical errors found in this evaluation sheet mainly belongs to the context of learning. It means that in the process of context of learning gives high influence to the transfer of English as foreign language in the term of process teaching and learning in the classroom through the materials used in the classroom. It might be concluded that context of learning is highly related to the setting where the students learn English language whether it is involved into setting of time or setting of place. This case also can be identified as developmental error in understanding English language as the target language.

\subsection{Intralingual Error}

Intralingual error refers to the errors which are made by the learners on their own interpretation on English structure as the target language while this interpretation leads into grammatical overgeneralization. Although this study discusses the materials of odd midterm evaluation which mainly produces the errors related to context of learning, it can't be ignored to elaborate intralingual error taken from this evaluation sheet because intralingual error highly connected to the English grammatical rules.

\subsection{Interlingual Error}

Interlingual error sometimes is called as negative transfer done by the users of English language. It happened because they are influenced by the use of mother tongue (in this context is Bahasa Indonesia). It means that 
interlingual error is produced within the interaction in the form of using English language as foreign language and Bahasa Indonesia as the mother tongue.

There are some errors which are found by the writers related to interlingual error inside odd midterm evaluation such as: the use of "at his office", "Let I'll", " a stomachache \& a headache", do you have some money" can be known as literal translation by Bahasa Indonesia. This happened because there are some different rules in Bahasa Indonesia and English language to construct sentences and their meanings. For instance in telling quantifier "some" which means "beberapa" in Bahasa Indonesia while in English language to indicate interrogative and negative meaning for quantifier must use "any not some". Other example is the use of preposition "at". In Bahasa Indonesia preposition "at" means "di or pada" while in English language it has specific meaning which is used to show specific context.

\section{DISCUSSION}

This odd midterm evaluation is kind of test that measure students' understanding about the materials given whether it is cognitive skill or affective skill. This test also becomes a tool for the teacher to indicate success in the process of teaching and learning in the classroom or school context. Furthermore, in discussing the items of the questions inside this mid oddterm evaluation, it has been linear with the syllabus of English language from the government for vocational students class XI. Besides that the test provides large number of items which is divided into some parts; dialogue (multiple choice) reading text (multiple choice and short answer), and essay. From all number of the test (82 numbers) which consists of multiple choice (50 questions), filling the blanks (20 questions) and essay (12 questions), this odd midterm evaluation has six grammatical errors from all. It might be said that it is proof that everyone including teacher who teaches English language can't avoid the grammatical errors.

As it is known that the test is a tool to know the process of teaching and learning, the teacher is supposed to provide the items inside the test correctly although errors can't be avoided beyond the process. It means that as a teacher can make errors in practicing English language as the target language which is not mother tongue. According to Brown (2000), errors in teaching and learning target language happened in fours categories; 1) interlingual errors, 2) intralingual errors, 3) context of learning, 4) various communication strategies the learners use.

Since the errors found in the materials inside odd midterm evaluation which is classified into the situation context where the process of teaching and learning takes place, it can be summarized that the errors in this process mainly about context of learning. However, the errors also occurred through interlanguage and intralanguage transfer. It happened because the teacher who has made the questions for this odd midterm evaluation is Indonesian while the teacher makes the test for the target 
language evaluation. It might be said the way that the teacher can't ignore the errors in arranging questions inside this odd midterm evaluation through both of interlanguage and intralanguage transfer.

\section{CONCLUSION}

According to the findings and discussions in chapter four, the writers conclude kinds and source grammatical error founds in odd midterm evaluation in Vocational School 2 Muhammadiyah, Parung Serab, Kota Tangerang. There are six grammatical errors found in this evaluation. They are errors in tense (Present tense and Past Continuous tense), Preposition, Object Pronoun, Article and Quantifier. The types of these grammatical errors are different to each other. There are three numbers with errors in present tense. The types of these errors are misformation (alternating-forms) and omission. It is found one number of with error in Past Continuous tense. The error in this type is classified into misordering. There is one number of grammatical error related to Preposition in this odd midterm evaluation. The error in this case is classified into misformation (archi-forms). The error related to Object Pronoun occurred because of misformation (archi-forms) while error related to Article because of addition (simple addition). Lastly, one number found of grammatical error which belongs to quantifier. The error in this type is classified into misformation (archi-forms).

The source of grammatical errors mainly is about context of learning because it becomes of one source for the students to learn English language. Although other sources such as interlanguage and intralanguage can't be avoided in this process. Interlingual error lies on the effect of literal translation from Bahasa Indonesia to English language or vice versa. Intralingual error refers to the errors which are made by the learners on their own interpretation on English structure as the target language while this interpretation leads into grammatical overgeneralization which lead into misformation, misordering, addition, etc.

However, these grammatical errors can be avoided by everyone who practices English language as target language including in the practice of teaching and learning. Furthermore, these grammatical errors become the proof as the concept of over generalization in English language for the second language acquisition because through these errors everyone who practices English language for communication shows the progress in understanding the target language and its structure.

\section{REFERENCE}

Brown, H.D. (2007). Principles of Language Learning And Teaching $5^{\text {th }}$ Edition. New York: Pearson Education, Inc.

Brown, H.D. (2000). Principles of Language Learning and Teaching $4^{\text {th }}$ Edition. New York: Addision Wesley Longman.

Ellis, R. (2008). The Study of Second Language Acquisition. $2^{\text {nd }}$ Edition. Oxford: OUP

Erdogan, Vacide. (2005). Contribution of Error Analysis to Foreign 
Language Teaching. Mersin University Journal of the Faculty of Education, 1(2), 261-270.

James, C. (2008). Errors in Language Learning and Use: Exploring Error Analysis. New York: Routledge.

Kiser, E. (2009). In Error? Grammatical is A Legimate Adjectives. Winston-Salem Journal.

Krashen, S.D. (2006). Language Two. New York: Oxford University Press.

Miles, M.B. and Huberman, A.M. (2003). Qualitative Data Analysis $3^{\text {rd }}$ edition. London: SAGE Publications, Ltd.
Nzama, M. V. (2010). Error Analysis: A study of Errors Committed by Isizulu Speaking Learner. Esikhawini: University of Zululand

Richards, J. C. (2004). $3^{\text {rd }}$ edition. Error Analysis: Perspectives on Second Language Acquisition. London: Longman.

Shohamy, E. (2001). Second Language Research Method. Sixth Edition. Oxford: Oxford University Press.

Suseno, Muchlas. (2014). Roles of Feedback to Overcome Grammatical Problems of Academic Writing in EFL Class. The $61^{\text {st }}$ TEFLIN International Conference, UNS Solo. 
